\title{
LIFE SKILLS ORIENTATION IN MADRASAH CURRICULUM
}

\author{
Ahmadi \\ Sekolah Tinggi Agama Islam Negeri (STAIN) Ponorogo \\ Jl. Pramuka No. 156 Ronowijayan Ponorogo \\ Email : ahmadibardan@yahoo.com
}

\begin{abstract}
This article intends to elaborate a charge include life skills opportunities in both madrasah curriculum of ibtidaiyah, tsanawiyah and aliyah. The approach used is the science of Islamic education. Some important concepts in Islam that allows it to be analyzed and used as the basis of life skills-based curriculum contained in QS. Al-Ghâsyiyah [88]: 17-20, QS. Fâthir [35]: 39, QS. Al-Jâtsiyah [45]: 12-13, QS. Al-A'râf [7]: 56-85 and QS. Al-Hujurât [49]: 1, 13, 18. Ethical values (Rasul Muhammad) Islam that allows elaborating life skills is shiddiq, amanah, fathanah and tabligh. The fourth value is assumed to equip graduates of madrassas that he later had a number of personal, social, academic, vocational and soft. The fourth value is assumed to equip graduates of madrassas that he later had the skills. A number of core Islamic values should be in synergy with the age issues such as democracy, globalization, the mastery of science, technology and information (the environment).
\end{abstract}

Keywords: Life skills, Curriculum, Madrasah

\begin{abstract}
ABSTRAK
Artikel ini bermaksud mengelaborasi sejumlah peluang memasukan muatan kecakapan hidup dalam kurikulum madrasah baik ibtidaiyah, tsanawiyah maupun Aliyah. Pendekatan yang digunakan adalah ilmu pendidikan Islam. Beberapa konsep penting dalam Islam yang memungkinkan untuk dianalisis dan dijadikan dasar penyusunan kurikulum berbasis kecakapan bidup terdapat dalam QS. Al-Ghâsyiyah [887: 17-20, QS. Fâthir [35]: 39, QS. Al-Jâtsiyah [45]: 12-13, QS. Al-A'râf [7]: 56-85 and QS. Al-Hujurât [49]: 1, 13, 18. Nilai etis (Rasul Mubammad) Islam yang memungkinkan dapat dielaborasi menjadi kecakapan bidup adalah shiddiq, amanah, tabligh dan fathanah. Keempat nilai ini diasumsikan dapat membekali lulusan madrasab agar ia kelak memiliki sejumlah kecakapan personal, sosial, akademik, vocational dan soft. Keempat nilai ini diasumsikean dapat membekali lulusan madrasah agar ia kelak memiliki sejumlah kecakapan baik personal, sosial, akademik, vocational maupun soft. Sejumlah nilai inti keislaman tersebut harus bersinergi dengan isu-isu zaman seperti demokrasi, globalisasi, penguasaan sains, teknologi dan informasi (lingkungan).
\end{abstract}

Kata Kunci: Kecakapan hidup, Kurikulum, Madrasah 


\section{INTRODUCTION}

A good quality of education, in this time, is a very important requirement for human life. Mulyasana (2011: 120)"education must be able to mature student's quality life by improving their skills, abilities and talents". Miller and Seller (1985: 144), "by education, then, the divine essence of man should be unfolded, brought out, lifted into consciousness and man himself raised into free, conscious obedience to the divine principle that lives in him and to a free representation of this principle in his life". Based on National's Laws Number 20 year 2003 about National Systems of Education (SISDIKNAS) Chapter of II section 3, has explained that the function of national education has to develop the student's abilities, form Nation's character in order to be a smart citizenship, expand student's potential in order to become a religious man and a complete submission to God All Mighty, have good attitudes, live in healthy, belong knowledges and become capable, creative, self-independent, democratic citizen whereas responsibility (Sinar Grafika, 2007: 5).

The above values are different with the fact that has happened recently. The implementation of National Finalt Test (UNAS) (Jawa Pos, 9th June 2009) reported that Independent Team Watcher (TPI) UNAS in school year 20082009 that there were 34 Senior High Schools and 19 Yunior High Schools have conducted insincerity at UNAS. It's almost $80 \%$ in black and grey colour, whereas white group only $20 \%$ (Supriatna, Jawa Pos, $4^{\text {th }} 3$ 2010). Parkay (2006: 53)" survey in ACE showed from 25.000 students amount of senior high school in America there are 62\% conducting insincerity in test, 12\% thieving in shop and $40 \%$ conducting falsehood of savings". Commission Protection of Child Indonesia (KPAI) Freey Devi Johanes deputy of KPAI reported that $97 \%$ child age 12-18 year old have seen porno films. Other Result, 93\% children have conducted sexual activities, $62.7 \%$ is not virgin and $21 \%$ children under 18 years old have done an abortion (Johanes on Pikiran Rakyat, 24th $-6-2010$ ).

Social problems that have been done by most of students have made their parents, teachers and goverment worried deeply. Those have to look for a solution as quickly as possible. Zarkasi Wahyudin, Head on Education Affair of West Java, said that to avoid the hoisterous of disease of society generated by all students needs education of character (Seputar Indonesia, 27th-10-2010).

This article intends to elaborate a charge include life skills opportunities in both elementary schools madrasah curriculum, Tsanawiyah and Aliyah. The approach used is the science of Islamic education. Some important concepts in Islam that allows it to be analyzed and used as the basis of life skills-based curriculum contained in QS. QS. Al-Ghâsyiyah [88]: 17-20, QS. Fâthir [35]: 39, QS. Al-Jâtsiyah [45]: 12-13, QS. Al-A'râf [7]: 56-85 and QS. Al-Hujurât [49]: 1, 13,18 . Ethical values (Apostle Muhammad) Islam that allows to elaborate a life skills is shiddiq, amanah, fathanah and tabligh. The fourth value is assumed to equip graduates of madrassas that he later had a number of skills in personal, social, academic, vocational and soft. 


\section{Lifeskill Conception}

Life skills are the ability of adaption and positive behaviour which can help individual to adapt effectively to demands and challenges of life in everyday. Samani (2007: 6) "ability to face and solve life problems wisely and creatively". WHO (UNICEF, 2005: 2 on www.unicef.org), 'life skills are abilities for adaptive and possitive behaviour that enable individuals to deal effectively with the demands and challenges of everyday life'. Sukmara (2003: 22), 'life skills represents individual's capability to face life problems without coming under pressure, later then by proactive and creative look for and also find solutions. Finally, they can overcome them as creatively as possible. Brolin: 'life skills include a wide range of knowledge and skills interaction, it's believed to be essential for adult independent living'. Hendrik: 'life skills can help an individual to be successful in a productive and satisfying life' (Anwar, 2006: 41-42).

\section{Life skills Models}

WHO (UNICEF, 2005: 2) has devided life skills as follows: 1) Communication and Interpersonal Skill that consists of: a) interpersonal communication skills, b) negotiation/refusal skills, c) empathy building, d) cooperation and teamwork and e) advocacy skills. 2) Decision-Making and Critical Thinking Skills that consists of: a) decision-making/problem-solving skills, b) critical thinking skills. 3) Coping and Self-Management Skills: a) skill for increasing personal confidence and abilities to assume control, b) take responsibility, c) make a difference, d) bring about change, e) skills for managing feelings and f) skills for managing stress. USBE (Anwar, 2006: 42) life skills devided to be five; 1) Life long learning; a) initiatives own learning, b) achieves high standards of literacy, c) manages information and d) demonstrates aesthetics awareness. 2) Complex Thinking Attributes; a) demonstrates a variety of thinking processes, b) integrates new information with existing knowledge and experience and c) applies thinking skills strategically. 3) Effective Communication; a) use appropriate methods to communication with others, b) responds appropriately when receiving communication. 4) Collaboration; a) understanding and serves in a variety of roles, b) facilitates groups effectively, c) uses resources effectively, d) work with a variety of population and e) responds appropriately to complex interrelationship. 5) Demonstrates: a) individual responsibility, b) practices a healthy lifestyle, c) understands and promotes the democratic principles of freedom, d) justice, equality and participates in activities that promote the good public.

From the above, the writer will classify intensively the model of life skills to be five styles as bellow:

First personal skills, personal skills relate to the ability of individual to see him/her actions in life by the usage of knowledge, attitude and skills. It has powered the individual to be able to manage his/her ownself, others and environment. There are two kinds of Personal skills. The first one is self- 
awareness. Mersino (2007: 33) "self-awareness is our ability to recognize our own emotions and their effects on us and others". Depdiknas (2007: 11) personal skills is an actualization through processing feeling to increase the sensivitas of apresiasivitas, the art of culture and also interest to expressing them. Mersino (2007: 25) "Self-Awareness which means understanding ourselves and our emotions. It involves the competencies of emotional self-awareness, accurate self-assesment and self-confidance”. Finally, self awareness relates to individual ability to see action in its life through exploiting of knowledge, attitude and efficiency to assist power in; (a) managing ownself (care self), (b) improving internal operation (internal increasing for skills of control of locus); developing trust of ourselves, awareness of ourselves to rights, values, attitude, weakness and strength, (c) efficiency to develop the skills for setting goals, (d) monitoring ourselves, ( e) managing feelings and ( f) managing stress. The second one is thinking skills. It is a capability of using ratio optimally. Depdiknas (2003: 23) and UPI (2007: 357) thinking skills is searching information, processing information and decision making skills and skills for creative problem solving). It will be developed until identifying the problem, variable and seeking solutions. Problem Solving can improve the ability of thingking skills and social skills. McGregor (2007: 44) "problem solving appears to offer excellent potential for nurturing thinking skills, if the problems are approached collectively in small groups, then many social skills can also be encouraged and developed to enhance collaboration". Problem solving by collaboration can also improve the ability of thinking skills and social skills. Polya (McGregor, 2007: 44) 'the first phase is about understanding a problem; the second about devising a plan; the third carrying out a plan and fourthy to examining the solution'. The following tabel showed us about classification of thinking skills based on KS3 National Strategy:

Categorization of Thinking Skills Based on the KS3 National Strategy (McGregor, 2007: 33)

\begin{tabular}{|l|l|}
\hline Thinking skill descriptor & Spesific constituent cognitive functions \\
\hline $\begin{array}{l}\text { Information processing skills } \\
\text { (developed by locating and }\end{array}$ & - - Sinding relevant information \\
collecting & - Sorting/classifying/sequencing \\
information) & information \\
& - Comparing/contrasting information \\
& - Indentifying and analyzing relationship \\
\hline Reasoning skills & - Giving reasons for opinions/actions \\
& - Inferring \\
& - Making deductions \\
& - Making informed judgement/decision \\
& - Using precise language to reason \\
\hline Inquiry & - Asking questions \\
& - Defining questions for enguiry \\
\hline
\end{tabular}




\begin{tabular}{|l|l|}
\hline Thinking skill descriptor & Spesific constituent cognitive functions \\
\hline & - Planning research \\
& - Predicting outcomes \\
& - Anticipating consequences \\
- Drawing conclusions
\end{tabular}

Second social skills, En.wikipedia.org (2011), "Social skills are any skills facilitating interaction and communication with others". Handayani (2009: 3) and Depdiknas (2003: 16-17) "social skills is closed relationship with interpersonal skills that covered communication and collaboration skills". Project Management Body of Knowledge (PMBOK) (Mersino, 2007: 17)'interpersonal skills are further defined by the following: effective communication, influencing the organization, leadership, motivation, negotiation and conflict management and problem solving'. There are some strategies to apply the effective communication that were introduced by Ditpais Kemenag (2011: 64)"there are five principles constructed in REACH; Respect, Empathy, Audible, Clarity and Humble".

Third academic skills, Anwar (2006: 30) and UPI (2007: 358), "academic skills involved the ability of identifying variables and describing relationship among of them, constructing hypotheses, designing and implementing a research. Johnson (2010: 9-13) has proved the ability of academic skills based the following phrases; "(i) it places thinking firmly on the side of 'knowing-how' rather than 'knowing that', (ii) it focuses attention on 'being explicit about component of the skills', (iii) it stresses 'learning by observing and modelling', (iv) it points out 'the importance of practice'. Mc Guinness Johnson, 2010: 3233) several general taxonomies' of thinking skills;

The different kinds of thinking are: sequencing and ordering information; sorting, classifying, grouping; analyzing, identifiying part/whole relationships, comparing and constrating; making predictions and hypothesizing; drawing conclusions, giving reasons for conclusions; distinguishing fact from opinion; determining bias and checking the reliability of evidence; generating new ideas and brainstorming; realating cause and effect, designing a fair test; defining and clarifying problems, 
thinking up different solutions, setting up goals and sub-goals; testing solutions and evaluating outcomes; planning and monitoring progress towards a goals, revising plans; making decisions, setting priorities, weighing up pros and cons.

Anderson, et al. (2001: 27), "we settled on four general types of knowledge; Factual, Conceptual, Procedural and Metacognition”. He also said (2001: 30-31) "the categories range from the cognitive processes most commonly found in objectives, those associated with Remember, through Understand and Apply, to those less frequently found, Analyze, Evaluate and Create".

Anderson, et al (2001: 27-31) said so far that the knowledge dimension clarified as follows; Factual knowledge-the basic elements students must know to be acquainted with a discipline or solve problems in it (knowledge terminology and knowledge of specific details and elements). Conceptual knowledge-the interrelationships among the basic elements within a larger structure that enable them to function together (knowledge of classifications and categories, knowledge of principles and generalizations and knowledge of theories, models and structures). Procedural knowledge-How to do something, methods of inquiry and criteria for using skills, algorithms, techniques and methods (knowledge of subject-specific skill and algorithms, knowledge of subject-specific techniques and methods and knowledge of criteria for determining when to use appropriate procedures). Metacognitive knowledgeknowledge of cognition in general as well as awareness and knowledge of one own cognition (strategic knowledge, knowledge about cognitive tasks, including appropriate contextual and conditional knowledge and self-knowledge). Remember (recognizing and recalling). Understand (interpreting, exemplifying, classifying, summarizing, inferring, comparing, explaining). Apply (executing, implementing). Analyze (differentiating, organizing, attributing). Evaluate (checking, critiquing). Create (generating, planning, producing).

Fourth vocational skills, vokasional skills represent an efficiency which concentrated to vocational ability. It refers to an efficiency of certain work area which is in society. Vocational skills used to obtain a work. It also used to develop profession so that it obtains the compensation of finansial competent status.

Vocational skills can give an opportunity to educative participant to get mixed up with various experiences. Billett (2011: 22);

Their educational purposes are primary concerned with (i) identifying the knowledge required for effective performance in an occupation; (ii) organizing experiences for the learning of that knowledge; (iii) finding ways of enacting the experiences so that learners can become effective in occupational practices and (iv) also be sustained in that effectiveness across working life including transitions to other occupations. 
Vocational skills is also a paradigm belongs two dimentions both personal and social aspects. Billett (2011: 17) "it is this negotiation between the personal and social that is essential to the enactment of vocations as occupations, their remaking and transformation and important roles of overcoming social and personal disadvantage". Dewey (Billett, 2011: 162), 'an occupation is the only thing that balances the distinctive capacity of an individual with his/her social services'. So Billett (2011: 162) gave some advices that those must have a correlation between of them.

Securing individuals' fitness for particular occupations and developing their readiness to work stand as key purposes or goals for vocational education. Indeed, alighning individuals' capacities and preparing them to be ready to engage in their preferred occupation is a key purpose of vocational education. These goals are held to comprise (i) identifying and guiding individuals towards careers in which they are interested and which they are suited to, (ii) developing individuals'capacities to engage in their selected occupation, (iii) understanding and meeting their needs and readiness, (iv) providing authentic experiences of work to engage with and understand the occupation in the world of work and (v) engaging reluctant learners.

Both academic and vocational skills should be complemented each other. Work area has emphasized skills of manual, after that also needs academic skills. That way on the contrary, work area is emphasizing academic skills, after it also needs vocational skills. There are some objectives of vocational skills. Billett (2011: 145) said that;

Purposes that have a more social orientation comprise; (i) developing the kind capacities required by employers, (ii) developing the kind of capacities needed to sustain and develop further an industry sector, (iii) practising that occupation in ways that are mindful of environmental and community concerns, (iv) developing the capacity to contribute towards national economic well-being and assisting workers to resist unemployment.

From the above presentation, the vocational skills has to focus at the followings; i) having goals and target that are able to give some informations about the needed requirements at the job, ii) giving an information to the students about an activity in job world, also assisting them to choose an appropriate work and need their capacities, iii) equiping all students about development of concept, procedure and needed disposition, iv) providing experiences to guarantee the target of education life as according to understanding of work world.

Fifth soft skill, Wikipedia (2011), "soft skills is a sociological term relating to a person's "EQ", the cluster of personality traits, social graces, 
communication, language, personal habits, friendliness and optimism that characterize relationships with other people.". The function of soft skills based on Klause (2001: 2)"soft skills complement the hard ones and are essensial for success in the rough-and-tumble work-place”. Klaus (2011: 2) explained intensively;

Soft skills encompass personal, social, communication and selfmanagement behaviors. They cover a wide spectrum of abilities and traits: being self-aware, trustworthiness, conscientiousness, adaptability, critical thinking, attitude, initiative, empathy, confidence, integrity, self-control, organizational awareness, likability, influences, risk taking, problem solving, leardership, time management and then some.

Elfindri, et al (2011: 95); There are nine types of soft skills that make a perfection to us. Those are; a) a complete submission to God Almighty, b) skills for communication, c) the forming of responsibility attitude, d) sincerity and on schedule, e) spirit fighting, f) taking a responsibility, g) accustomed to work hard in a team, h) skills of household and i) visionair.

\section{Madrasah as a Islamic Education in Indonesia}

The word 'madrasah' are isim makân of the word darasa-yadrusu-darsan wa durûsan wadirâsatan, meaning erased, missing scars, remove, making obsolete, training and learning (al Munjid, 1986). Based on definition the word 'madrasah' is the place to educate students, eliminate or eradicate ignorance of their ignorance and to train their skills according to their talents, interests and abilities. The knowledge and skills a person will quickly become obsolete in harmony with the acceleration of progress in science and technology and development of the times. Therefore, the madrasa is basically a vehicle to develop the knowledge, attitudes and skills on an ongoing basis, in order to stay up to date and do not quickly become obsolete.

Seen from history, there are two important factors behind the establishment of madrasah, namely: first, the view that traditional Islamic education system is felt less able to meet the pragmatic needs of the community, and second, there is concern over the rapid growth of the Dutch schooling that will lead to secular thought in society. To balance the growing secularism, Muslim societies, especially those reformist attempt to reform through education and empowerment efforts madrasah development.

Reality subsequent history shows that madras grew and evolved from, by and for the Islamic community itself. Means, Madrasah already been applying the concept of community-based education (communitiy based education). Indonesian people, both individuals and organizations, building madrasah to meet the needs of education, particularly religious, they are. No wonder they built it madrasah seem completely sober. Place them sober. Funding they manage potluck. Government's attention to them too lightly. They are more 
motivated by Islamic religious missionary zeal. Therefore, to date approximately $90 \%$ of the number of madrasah in Indonesia are privately owned. The remaining approximately $10 \%$ was owned by the state.

In East Java, in 2003, there were 7.167 Madrasah Ibtidaiyah and only $1.93 \%$ (138 madrasah) with the status of state. Remaining $98.07 \%$ or approximately 7. Madrasah Ibtidaiyah (MI) in East Java is private status. From the number of Madrasah Ibtidaiyah, they can accommodate as many as $1,027,675$ student learners. Students are accommodated in the State of Madrasah Ibtidaiyah as many as 25.252 students and there are 1,002,423 were accommodated in private Madrasah Ibtidaiyah. For Madrasah Tsanawiyah (MTs), from 2255 there were only 7.94\% with the status of state and the remaining $2076(92 \%)$ of private status. From the number of MTs can accommodate as many as 409,582 students learners, with details of 94857 learners MTs Negeri (State) and 314729 learners MTs Swasta (privat status). To Madrasah Aliyah of 837 Madrasah Aliyah only 9.8\% (82) the status of the land and the remaining $755(90.20 \%)$ of private status. From the number of MA students can accommodate as many as 159,674 students, with details of 54465 learners and 105209 learners MA Negeri (State) MA Swasta (privat status) (Muhaimin, 2010: 184-185).

The data above implies how high a spirit of independence Indonesian Muslim community, especially in East Java in madrasah education either MI, MTs and MA. The attitude of the Muslim community independence driven by religious zeal and missionary. Unfortunately masyarakt independence stance has not been accompanied by a pro-active attitude of the government in making policies that defend the madrasa especially private madrasah. Policy of the Government of Indonesia has not given the freedom and flexibility to private Islamic schools to develop education systems that are principle-based schools rather different school system. Madrasah education system based schools usually require a number of facilities (laboratories of life) are typical, such as mosques and decent housing and other facilities (information technology), which facilitates the interaction between the organizers of the Islamic community. More government attention to the development of public schools. Madrasah is still underestimated by the government. A number of policies issued by the government is less suited to the conditions and needs of madrasah. The books that were dropped by the lack of books needed by the madrasah. Madrasah need books and other religious literature of the Middle East instead of the West alone. Although books and reading materials from the west was not rejected by madrash.

Based on the above it is understood that there are multiple identity madrasah education institutions, namely: First, the madrasah are educational institutions and community-based integrated. Implementation of madrasah education embodies the aspoirasi and potential community, especially the Muslim community. Secondly they also prepared by the school studying 
advanced higher, eg for MA directed to follow-up studies to college they are interested. These three substances are given in the madrasah curriculum is the teaching of Islam in both the narrow and the broad sense. In a narrow sense the students are educated and taught a variety of science related to the religious sciences such as, Taubid, Akblak, Fiqh, Lughah Arabiyah and the Quran and the Hadits. In the broadest sense of the learners guided and trained to practice the teachings of Islam in daily life are integrated with the community. They were trained and supervised by teachers and kiai way community life, valuing science and apply a variety of technologies in a variety of life (usually agriculture and trade), being honest and loving people, and able to respond to changing times wisely.

The third characteristic associated with madrasah above, the most relevant in the context of life skills assessed is the level of madrasah aliyah. For this level, graduates are expected to have three basic competencies ie academic, social and religious. Academic competencies needed in preparation for further study go to college. Social competencies needed in order to provide those who can not continue their studies to college with the ability to adapt to the society that the average age of adults are married and coupled with the ability to search for basic livehood from farming and trade.

Religious competencies needed by those who will study up to the university in accordance with its path especially as STAIN, IAIN and UIN and for those who do not continue their studies to college can use this ability to be a religious preacher, religious teacher or a teacher of the Quran in the mosques and surau in neighborhood. If this profession seriously occupied in religious devotees were able to sustain their lives economically. More than that in psychology, especially social psychology, people who already have the stock a strong religious basis, typically have a number of tools that can curb people from acts contrary to the law and local norms. Less likely someone who understand and appreciate the religious attitude may well fall into immoral acts, or are depressed simply because of economic factors alone. For those madrasah graduates are expected to have an insight into the life history of success that sees that life is not only the welfare of the world, but also take into account the safety of the Hereafter.

Life is to make a moving, changing and expanding. Life not merely simply eating, drinking, sleeping, and waking up but life is more of them. Muhaimin said (2008: 79),"Inna al hayah hiya al-harakah wa-al-harakah wa al-barakah hiya anni'mah wa ar-ziyadah wa as-sa'âdah". In the perspective of Islam that human life does not just live in world but also live in the day of resurrection (akherat) so that journey of life has the character of limited and whereas is bringing certain consequences an endless life especially in the day of resurrection. Human life in world become a leader (khalifah) and become Allah's slave which always serves to Him. 


\section{Life Skills Orientation on Madrasah Curriculum}

Development of madrasah education can not be treated by partial but must be considered and dealt with as a whole. For that is the development of a national education policy that has the vision to realize the social system pranatas pendidikann as strong and authoritative in empowering all citizens of Indonesia to become a quality human being. Human quality and proactive in turn able to answer all the challenges of the times are always changing (SISDIKNAS Law. 20/2003, on Grafika, 2007).

Implementation of the policy vision of the Indonesian government over the historical practice has ups and downs. In the period of the Minister of Religious Affairs Mukti Ali Islamic discourse concept development through joint decree (SKB) 3 Minister who tried to align the quality of the public school madrassa. The government share madrasah curriculum with $70 \%$ share of the common material uncharged and 30\% charged religious materials. Judging from the central issue, Mukti Ali wanted to break the public's understanding of the Ahmadiyah Islamic discordant tone. Madrasah it was always placed in a marginal position because he just dwell on the study of Islam and the religious problems of the poor general knowledge so that its output was underestimated by the public. With the advent of the LCS 3 Ministers, people are starting to understand the existence of madrassas in the constellation of national education in Indonesia. But the spirit of the decree 3 ministers are not widely understood completely by the coaches and managers madrasa itself. $70 \%$ of the general knowledge portion and $30 \%$ of religious knowledge more widely understood symbolically-quantitative and not substantive. Finally, once again put out his still barren. Mastery of general knowledge madrasah graduates remain shallow and religious knowledge was actually tends to decrease.

In the period of the Minister of Religious Munawir Sadzali offer concept Madrasah Aliyah Special Program (MAPK). Madrasah is designed to anticipate the lack of graduates Madrasah Aliyah in the control of the religious field. At that time, the government hopes to address concerns Indonesian Muslim community who feel that the madrasas could no longer bear ulama / scholars who are good at mastering the books of Arabic and Islamic sciences. However, again limited understanding of the substance of Islamic madrassa organizers itself causes the program is stuck on the question of quantification, and the percentage of curriculum materials between common knowledge and religious knowledge (Muhaimin, 2010: 198).

At the time the Minister of Religious Affairs issued Tarmizi Thaher Islamic concepts as public schools distinctively Islamic. Quantitatively charge madrasah curriculum to public school is not much different but substantively very different. Islamic religious traits should not be lost in any given charge minister of learning to students of madrasah. All materials and any portion of the substantive quantitative peresentasi must reflect Islamic values in the broadest sense. Thaher policy followed by the Minister Malik Fajar. Fajar 
established the existence of at least three Islamic schools to meet the demands of the quality of madrasah at once, namely: 1) practicing the spirit of Islam in daily life, 2) align with the quality of public school madrassa, 3) responding to the demands of the time including the anticipated developments in technology and science, globalization and universal democracy (Muhaimin, 2010: 199).

In the next period of three quality is a major concern of the policy maker (Minister of Religion) organizing madrasah. They no longer get stuck on simbolistis curriculum, an important substantive, as an Islamic educational institutions, madrasas must reflect Islamic values in the widest possible sense. Improving the quality of both individuals and institutions advocated by Islam. Respond to the challenge also encouraged by the Islamic era. Improved ability and mastery of science and technology is also highly recommended by Islam. Therefore, generally the next Minister of Religion is not very question forms and types of curriculum set by the government (Ministry of education and culture). When the government issued a CBC and SBC curriculum implementation, madrasah responded positively to both even though the level of implementation masksimal less run. Conceptually all types and forms of curriculum whatever remains acceptable, as long as it does not eliminate the learning curriculum and Islamic religious education. The organizers seemed to have pocketed madrasah joker card that can anticipate all forms of the game in this country curriculum. The joker card is an integrative understanding of the general science with theology. Even the new curriculum (2013) can be approximated by the card. In facing the challenges of the 21 st century Islamic world, it is more important that the madrasah not agree or disagree with the changes in the curriculum but instill the sense that any changes should be anticipated and addressed in the spirit of progress and improvement (QS. Ar-ra'd [13]: 11), Allah does not will change the destiny of a people unless they change themselves. So the change is necessary and should take place towards the goodness/virtue.

Based on the above conditions have designed a madrasah curriculum that can answer all challenged the Islamic world of the 21 st century. Nasr said that (Muhaimin 2003) there are about 11 challenges that will inevitably be faced by the Muslims of the 21st century, namely 1) the environmental crisis, 2) globalization and, 3) post-modernism; 4) secularization; 5) crisis of science and technology; 6 ) the penetration of non-Islamic values; 7) improved the image of Islam; 8) revitalization of Islamic civilization; 9) feminism and gender; 10) Human Rights; 11) internal matters of Islam (David. 2005 and Fidler. 2002).

Making the madrasah as a vehicle to foster the spirit and practice of Islamic life, especially in the Islamic world to answer the challenge of the $21 \mathrm{st}$ century necessitates madrasah creating a curriculum that can deliver graduates who not only understand and master the knowledge and skilled use of technology but also ready to live and work in the community in emission control and teachings and values of Islam. This is the essence of life skills-based curriculum madrasah version. 
Curriculum-based life skills development must be conducted by school experts based on strategic management, so they should make several steps programs as follows; 1) Analizis the school's strength, weakenesses, opportunities and strength. 2) Formulation strategic choices. In this case, the school committee and the head master should select any kind of strategies such as: a) vertical corporation strategy, b) aggressive strategy, c) divesment strategy, d) concentric diversication strategy, e) rational strategy, f) market driven strategy, g) competence based strategy, h) process based strategy, i) context based strategy and h) non rational based strategy (David. 2005 and Fidler. 2002).

Madrasah strength lies in the vision of Islam that timeless and universal. Murrata and Chittik in The Vision of Islam suggested that the drug used to treat a variety of community problems such as hunger, disease, oppression, pollution, and a variety of other social ills is to return to God through religion (1994). However the traffic of human life there is a set that is God Almighty. It was he who set the rules either general or detailed value. This value is contained in the Quran and Hadith are then applied in everyday life. These efforts produced a distinctive understanding of Islamic life. Life Skills madrassa version presupposes the understanding, application and thresholded values of life that Muslims from all over the Islamic organizers.

There are lots of steps to realize life skills orientation in education; 1) Formulate school's vision. The school's vission dedicated to exceeding the expectation of life skills. 2) Formulate the school's mission, goals and target based on life skills orientation. 3) Formulate the school's outcomes. 4) Select subject matters that are oriented to life skills. 5) Insert the life skills values to all learning activities. 6) Design several local subjects to be life skills subjects matter. 7) Formulate the several schools' activities to become a life skills program. 8) Formulate the school's program that serves to life skills implementation. 9) Develop the ability of the curriculum's personal such as; teacher, school's employee, school superintendent, librarian, laboratory staff and school committee throught curriculum workshop, seminar and shortcourse. 10) Make collabotation both internal and exsternal institution.

Characteristics of teachers or teaching professional for just a particular subject area as applied in public schools reconstructed with the characteristics of a professional chaplain, reflected in all its activities as murabbiy, mu'allim, mursyid, mudarris dan mu'addib. The meaning of the preachers is reflected in the professional life of dedication attitude, commitment to the process and the work and attitude of continuous qualitiy impprovement (improved quality on an ongoing basis). As mu'allim, preachers have mastered the science and be able to develop a more critical and may explain its function in everyday life. Here a cleric must have two skills are required as well as the theoretical and practical dimensions and knowledge transfer/internalization in the form of daily amaliah. As Murrabi, preachers_must be able to prepare students to be able to be creative, and able to manage and maintain his creation to not cause havoc catastrophe for 
people and the natural surroundings. As murshid, chaplain must be able to be a central model or identification, or be the center of modeling, model and consultant to the learners. As mudarris, preachers must have a sense of intellectual and information and update their knowledge and skills as well as sustainable and strive to educate all learners, eradicate ignorance, as well as skills training according to their talents, interests and abilities. As muaddib chaplain should be able to be responsible in building an advanced civilization in the future.

The curriculum experts, especially, teachers have to formulate the teaching-learning process based on multiple life skills cycles in order to gain a sustainable-values smart life in competitive complexity era. Thinking skills must product several sciences and technologies because Allah Almighty has supplied several capabilities in every human being. Essencially, they have a brain that can use as an analogical reasoning.

Life skills orientation madrasah curriculum should be developed in an integrated manner. Teachings and values of Islam be the source of information and guidance and consultation for the development of a variety of subjects including general studies sort IPS, science and skill and art. Chaplain or religious teachers can work together with other teachers in all subjects that contained the teachings of religion. This means studying public, outside of the science of religion is also a worship. So that the students get the impression that there is no dichotomy and discrimination in studying both the general public and the science of religion. Everything is sought within the framework of worship.

In the context of the development paradigm of Islamic education, the organismic system in education is very suitable to be applied in the implementation of the madrassa curriculum based on life skills. The Ustadz need to understand the relationship between the values of faith and devotion to the subject/field of study cultivated. In this sense, the chaplain must be literate (master) field of science. Here the preachers should really competent academically (academic competence). Islamic parties should no longer tolerate preachers or teachers with a Bachelor of Religion (SAg.) teaching science or social studies. Teachers IPA or IPS and non-religious subjects (such as art, sports and language) should really be in accordance with their respective fields. However, except to be professional in their subject areas, respectively, preachers or teachers at the madrasah must be able to translate the science into the faith and piety values contained in the teachings of Islam. This does not mean that the science teacher, social studies, sports, language and arts should also at once a religious teacher. Let them remain supposed experts and professionals in the fields of non-religious. Conversely also should not be teachers of religion such as Figh, Quran, Hadits, Akblak, Tasawuf, Taubid or Qiraatul Kutub burdened with the task of teaching the areas outside the field of his/her ability. Even the exquisite, a religious teacher/teachers of Fiqh_ only teaching of Fiqh field, and should not be teaching other fields such as ethics, hadits or tashawwuf though still 
clump together in religious sciences. Professionalism and competence of a teacher/chaplain in the academic field, both in the field of general and religious knowledge must be equally enforced strictly and responsibly. If violated, the gamble is the loss of authority of the scientific discipline. If this is the case then the discipline will be destroyed (loss of existence).

Translating sciences (especially non religious sciences) to the values of faith and Islam in the broadest sense should not be confused with the context of expertise, and authority profesionalism each area of science. Translating science to values and Islamic faith should be placed in the context of "insight". Teachers of religion must be an expert in the field of religious and non-religious teachers must also be an expert in the field of non-religious subjects. Teachers of religious experts in the field of religion should have a broad scientific knowledge related to the understanding of non-religious sciences. There should be no assumption that the science of religion that the most important and most major than non-religious sciences. Religious teachers just have to convince the students/learners particularly interested in the non-religious sciences that study the non-religious sciences were part of worship and highly recommended in Islam. There should be no impression dichotomy between the two. Contribution of science non-religious spirit of the religious sciences is the attitude and awareness that all of science is always evolving. There is no absolute truth nature of science, including the science in the field of religion. This realization became the driving spirit and the religious sciences that are constantly evolving and developed to a more advanced line with the challenges of his time. The door of ijtihad must always be opened, because only with ijtihad and creative dimension in keilmuanlah a science can be better and more advanced. Instead, teachers/preachers who teach general science fields, such as mathematics, physics, chemistry, biology, sport and the arts should not assume that the field ilmunyalah best because it is considered a well-established both methodologically and substantively. Teachers/preachers who teach the sciences should not be condescending teachers/preachers of religious sciences field. Math and Physics teacher should not assume that he is smarter than the teachers/preachers who teach science Nabwu/sharaf and science of fiqh. After all no one is an expert, and experts in all fields of science perfectly. Science God is very broad and many. Humans are not perfect is not possible to master and become an expert in all areas of science. People should not proficient in one area but not necessarily smart in other areas. Therefore, each scientist must coexist and that dialogue among the religious science that happens harmonization, mutual respect and complementary. In the discovery of the sciences to the experience, with the help of the religious sciences gratitude to god there is a dimension of the omnipotence of the Creator, so that the chest and mind scientists increasingly embedded faulty faith and devotion to the Creator. Having managed to uncover the secrets of nature, scientists are not necessarily being arrogant. On the contrary scientists are increasingly tawadlu because it assumes 
that the new findings reveal that a small fraction of the mysteries of nature is not infinite. It was only in the field or specialization scientific perspective, even finding it had to be recognized as the findings are not necessarily true in absolute terms. True true scientist should be able to make room for the truths proposed by other scientists.

The quality of madrasah curriculum oriented developing the life skills lies in the consistent and whether the quality of the practice of philosophy of life, attitudes and life skills such as the Islamic perspective of the core curriculum. Associated with this, there are some fundamental questions that form the core of the commitment and consistency in the practice of Islamic way of life, which are as follows: 1) what will be done by graduates with personal?, 2) what will be done by him yag physical environment?; 3 ) what the social environment for themselves and what is to be done by him in his social environment? ; 4) what will be done to the descendants or future generations?

In order to answer question number one, in QS. At-Tahrîm [66]: 6 states that believers should maintain, and improve the quality protect the self and family to not experience the pain of living (hell). Establish, maintain and improve the quality of yourself in terms of the physical-biological means to maintain and improve the quality of health of the body. While in terms of development effort involving psychological aspeks IQ (Intelligent Quotient), EQ (Emotional Quotient), CQ (Creativity Quotient) and SQ (Spiritual Quotient). In the context of education at the school, the curriculum or educational programs need to be designed and directed to assist, guide, train and teach and/or create an atmosphere where the students can develop and improve the IQ (Intelligent Quotient), EQ (Emotional Quotient), CQ (Creativity Quotient) and SQ (Spiritual Quotient) (http://id.wikipedia.org). IQ Education on increasing the quality of the head so that learners become smart and clever. EQ on increasing the quality of education so that learners Heart to be a spirited competition, patient, humble, maintain self-esteem (self-esteem), empathy, love kindness, unable to control himself/lust and do not rush into a decision. CQ concerning the quality of education so that learners Hand become agent of change, able to innovate or create something new. SQ involves improving the quality of education so that learners be honest people who believe and fear Allah, noble, to be trust in the holding position, and possesses shiddiq, amanah, tabligh dan fathanah.

In order to answer the second question of the Quran (QS Al-Ghâsyiyah [88]: 17-20) has explained that a person's attitude should be developed on the physical environment is to understand that the universe is teleological (has a clear purpose). All that should be understood by man to be aware of the greatness of God as the creator and awaken people to the provisions of that man accountable for his life to the Lord. Man is destined to become a manager and heir (caliph) on earth. Those who oppose and deny his role as caliph he would break himself (QS. Fâthir [35]: 39). Humans are also told that God's grace 
bestowed by the heavens and the earth is for man and he was given the ability to reason and understand all the various secrets of nature and enjoy all the benefits contained in nature (QS. Al-Jâthiyah [45]: 12-13); Al-Baqarah [2]: 29 and QS. Luqman [31]: 20). Man banned for mischief regular and orderly. Instead he was told to do good and keep all the existing order (QS. Al-A'râf [7]: 56-85). In the context of education at the school, educational programs or curriculum Science (Biology, Chemistry and Physics) need to be designed to be directed to the effort to help, guide, train and teach and/or create an atmosphere where the students appreciate nature and should not damage it. In other words, the basic competencies and learning outcomes of science education in Madrasah emphasis on the establishment and the capability memahmi accept with gratitude the physical environment, and the ability to use it without destroying it (Thiba'at, $1413 \mathrm{H})$.

In order to answer question number three in the QS. Al-Hujurât [49]: 118, among others explained that people should develop an attitude of children towards their social environment. Human banned from laughing, mocking and cursing. Humans also have to be tolerant, open and not being exclusive. The consequence of the attitude of children is that it must be able to reconcile the conflicting parties or fight. Brothers attitude is not limited to the local environment but also national, regional and global (QS. Al-Hujurât [49]: 13). Means humans need to foster transnational social attitudes. Nationalism must learn to coexist with regionalism and globalism without losing its meaning and its power as a source of political vitality. Educational programs or social studies curriculum and civic education should be designed and directed the effort to help, guide, train and teach and/or create an atmosphere where the students have an attitude and a sense of brotherhood towards different kinds of social environments increasingly wide geographical scope, both related to social environment local, regional, national, regional and global social environment. Consequently, foreign language education needs to be developed intensively, both for Arabic, English Languages and other foreign languages, especially languages of technologically advanced countries such as Japan and China. So that future students can learn their cultures so they can become more advanced.

The answer for question number four is accumulation and combination from tree answer before. Symbol of above question and answer included on QS. Al-Furqân [25]: 74 that is and those who pray, " our lord! Grant unto us wives and offspring (teacher, educational personeel, and student) who will be comported of our eyes (heart), and (another person) give us (the grace) to lead the righteous.

Regarding to the structure of the curriculum of secondary education curriculum (new) 2013 which contains the following subjects: 1) Islamic Education, 2) Pancasila and Citizenship Education, 3) Indonesian; 4) Mathematics, 5) the history of Indonesia, 6) Language England; 7) Art and Culture; 8) pre-work and; 9) sports physical education and health coupled with 
an average of 4 subjects in the group and 4 specialization elective subjects, the curriculum madrasah Aliyah (MA) can be divided into groups groups are as follows: 1) group a and B (mandatory), which is 9 subjects with the possibility of modifying the course of Indonesia's history, combined with the history of Islam in Indonesia, arts and culture into the art of Islamic culture such as art reading the Qur'an, pre-work to be pre-Islamic values such as work-based Muslim fashion, 2) group C (specialization), the 4 subjects (Tafsir, Quran,Hadis; faithmoral; Ushîl fiqh or fiqh) and 3) the subject matter of choice, ie 4 elective subjects which are (a) media literacy Islam, another Foreign Languages (Arabic), applied technology management (propagation of Islam), and the choice of deepening interest (study of kepesantrenan). That is one of approach for research about things in order to be more meaningful. Six Sigma or DMAIC cycles (Defining, Measuring, Analysing, Improving, and Controlling) are assumed to applicable to conduct it. 3) Soft skills encompass Emotional Traith involed of personal, social, communication, and self-management behaviors. Those support to hardskills, example of Muhammad's behavior Shiddiq, Amanah, Tabliqh and Fathanah. 4) Social skills; every human being that has been created by God is to be familiar with others because he/she cannot live alonely. 5) Vocational skills; students have to create one of production based on their own competence that is meaningful for both themselves and others.

The combination of multiple life skills constructed in the teachinglearning process is a competence based curriculum. It can be described in the following chart:

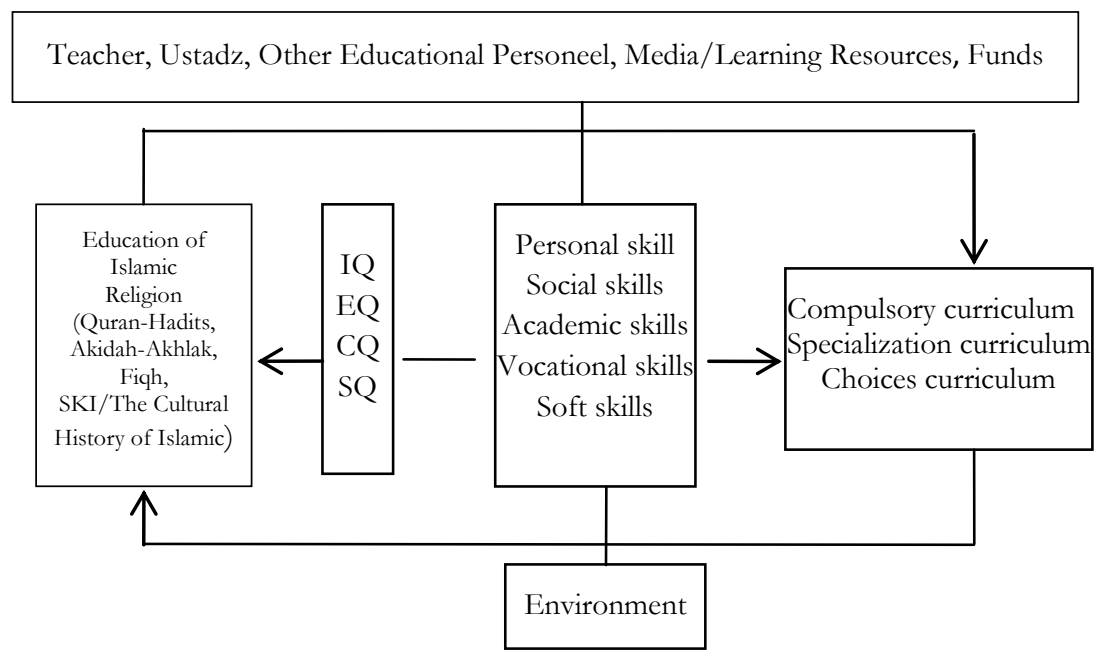

Explanation

IQ = Intelligent Quotient

$\mathrm{EQ} \quad=$ Emotional Quotient

$\mathrm{CQ}=$ Creativity Quotient

SQ = Spiritual Quotient 
SKI = The History of Islamic Civilization

$\longrightarrow=$ Implementation on madrasah curriculum

$\longleftrightarrow=$ Life skills orientation area on madrasah curriculum

$=$ Another factor which influenting to curriculum

The picture above shows that the study/science PAI consisting of quranhadits, akidah-akhlak, fiqh, Islamic cultural history and creating a religious atmosphere should be a commitment to every citizen in order to bring madrasah as a vehicle for the formation of attitudes and practices of Islamic life. The practice of Islam is at the core of life-oriented curriculum of life skills. PAI be a motivator for development of IQ, EQ, SQ and CQ. The quality of that intelligence should not only be controlled/owned but should also be practiced/applied in everyday life to become a real-life skills. In the PAI all subjects both incorporated in the compulsory curriculum, specialization and choice, when oriented in life skills after taking into account the potential environmental, teachers/preachers, other educational personnel, media/learning resources and funds.

\section{CONSCLUSION}

The orientation of life skills on madrasah should be based on the purpose of life is substantially outlined in Islam, the happiness in the world and salvation in the Hereafter. Certainly not enough to achieve the bablun min-Allah but also through hablun minan-nas. PAI lessons at the school in a way reflects the life skills and multiple intelligences. In principle there is no conflict between the life skills and multiple intelligences with the basic principles of Islam which wants the good of mankind. Successful orientation Life skills-based curriculum supported by the potential and the quality of teachers/preachers, other educational personnel, media/learning resources and adequate funding. Some important concepts in Islam that allows it to be analyzed and used as the basis of life skillsbased curriculum contained in QS. Al-Ghâsyiyah [88]: 17-20, QS. Fâthir [35]: 39, QS. Al-Jâtsiyah [45]: 12-13, QS. Al-A'râf [7]: 56-85 and QS. Al-Hujurât [49]: 1, 13, 18. Ethical values (Rasul Muhammad) Islam that allows to elaborate a life skills is shiddiq, amanah and fathanah, tabligh. The fourth value is assumed to equip graduates of madrassas that he later had a number of skills in personal, social, academic, vocational and soft. A number of core Islamic values should be in synergy with the age issues such as democracy, globalization, the mastery of science, technology and information. Intense dialogue between Islamic values are universal basic social and cultural reality of the ever-growing cause multiple intelligence theory was basically relevant to the teachings of Islam.

\section{REFERENCES}

Al Munjid. 1986. Fi al-Lughah Wa al- A'lam. Beirut: Dar al-Masyriq. Anderson, W. and Krathwohl. 2001. A Taxonomy for Learning Teaching, and 
Assessing A revision of Bloom's Taxonomy of Education Objectives. New York: Longman.

Anwar. 2006. Pendidikan Kecakapan Hidup (Life Skill Education). Cetakan II. Bandung: Penerbit ALFABETA.

Billet, S. 2011. Vocational Education, Purposes, Traditions and Prospects. New York: Springer.

David, F.R. 2005. Strategic Management Concepts \& Cases. Ninth Edition, New Jersey: Prentice Hall, Inc.

Depdiknas. 2003. Konsep Pendidikan Kecakapan Hidup. Edisi II. Jakarta: Depdiknas. Depdiknas. 2003. Pola Pelaksanaan Pendidikan Kecakapan Hidup. Jatim: Penerbit SIC Bekerjasama dengan LPKM Unesa, Swa Bina Qualita Indonesia.

Depdiknas. 2003. Undang-Undang Republik Indonesia No. 20 Tabun 2003 Tentang Sistem Pendidikan Nasional. Jakarta: Depdiknas.

Depdiknas. 2007. Pengembangan Model Pendidikan Kecakapan Hidup. Jakarta: Puskur Balitbang Depdiknas.

Ditpais Kemenag. 2011. Pengembangan Soft Skills Guru PAI. Materi Pendidikan dan Pelatihan Guru Pendidikan Agama Islam (GPAI) Tingkat Sekolah Menegah Atas (SMA) Sekolah Menengah Kejuruan (SMK). Jakarta: DITPAIS.

Fidler, B. 2002. Strategic Management For School Development Leading Your School's Improvment Strategy. London: Sage Publication.

Jawa Pos. 2012. Surabaya: 05-01.

Elfindri, et al. 2011. Soft Skills Untuk Pendidik. Baduose Media.

En.wikipedia.org/wiki/social skills. 14-12-2011.

En.wikipedia.org/wiki/soft skills. 18-12-2011.

Jawa Pos, 2010. Surabaya: $4^{\text {th }} 3$.

Jawa Pos. 2009. Surabaya: 9-6.

Johanes, F.D. 2010. Pikiran Rakyat. 24th-6.

Johnson, S. and Siegel, H. (2010). Thinking Skills. London: Continuum International Publishing Group.

Klaus, P. 2011. The Hard Truth about Soft Skills Workplace Lessons Smart People Wish' They'd Learned Sooner. Harper Collins e-books.

McGregor, D. 2007. Developing Thinking; Developing Learning, A Guide to Thinking Skills in Education. First Edition. England: McGraw-Hill House.

Mersino, A.PMP. 2007. Emotional Intelligence For Project Managers. New York: AMACOM American Management Association.

Miller, John, P., and Seller, Wayne.1985. Curriculum Perspectives and Practice. New York: Longman.

Muhaimin, et al. 2008. Paradigma Pendidikan Islam Upaya Mengefektifkan Pendidikan Agama Islam Di Sekolah. Bandung: PT Remaja Rosdakarya.

Mulyasana, D. 2011. Pendidikan Bermutu dan Berdaya Saing. Bandung: Penerbit PT. Remaja Rosdakarya. 
Parkay, F.W, et al. 2006. Curriculum Planning A Contemporary Approach. Eighth Edition. United State: Pearson Education, Inc.

Samani, M. 2011. Jawa Pos, 31 Desember 2011.Surabaya.

Samani, M. 2007. Menggagas Pendidikan Bermakna Integrasi Life Skill-KBK-CTLMBS. Surabaya: Penerbit SIC.

Samani, M. 2011. Jawa Pos. Surabaya: 31-12-2011.

Seputar Indonesia, 27th-10-2010.

Grafika, Sinar. 2007. Undang-Undang SISDIKNAS (Sistem Pendidikan Nasional). Jakarta: Sinar Grafika.

Sukmara, D. 2005. Implementasi Program Lifeskill Dalam Kurikulum Berbasis Kompetensi Pada Jalur Sekolah. Cetakan II. Bandung: Ms Mughni Sejahtera.

Supriatna, H. 2010. Jawa Pos.Surabaya: 4-3-2010.

Thiba'at, M.A.F. 1413 H. Al-Qur'an dan Terjemahannya. Madinah Munawarah: Asy-Syarif.

UNICEF. 2005. Life skills-Based Education in South Asia, A Regional Overview prepared for: The South Asia Life Skills-Based Education Forum. Bangladesh: UNAIDS.

UPI. 2007. Rujukan Filsafat, Teori dan Praksis Ilmu Pendidikan. Bandung: UPI. 